\title{
Heterogeneous $\mathrm{SnCl}_{2} / \mathrm{SiO}_{2}$ versus Homogeneous $\mathrm{SnCl}_{2}$ Acid Catalysis in the Benzo $[N, N]$-heterocyclic Condensation
}

\author{
Hossein Reza Darabi, ${ }^{\dagger+, *}{ }^{+}$Kioumars Aghapoor, ${ }^{\dagger}$ Farshid Mohsenzadeh, ${ }^{\dagger}$ Mohammad Reza Jalali, ${ }^{\dagger}$ \\ Shiva Talebian, ${ }^{\dagger}$ Leila Ebadi-Nia, $^{\dagger}$ Ehsan Khatamifar, ${ }^{\dagger}$ and Ali Aghaee ${ }^{\ddagger}$ \\ ${ }^{\dagger}$ Nano \& Organic Synthesis Lab, Chemistry \& Chemical Engineering Research Center of Iran, Pajoohesh Blvd., \\ km 17, KarajHwy,Tehran 14968-13151,Iran.*E-mail: darabi@ccerci.ac.ir,r_darabi@yahoo.com \\ ${ }^{\star}$ Shifa Pharmed Industrial Group Co., Kordan, Karaj, Iran \\ Received September 20, 2010, Accepted November 14, 2010
}

\begin{abstract}
The scope of homogeneous Lewis acid-catalyzed benzo[ $N, N]$-heterocyclic condensation was expanded to include the use of various metal salts not reported in the literature and $\mathrm{SnCl}_{2} \cdot 2 \mathrm{H}_{2} \mathrm{O}$ was finally selected. Among various solid supports activated with $\mathrm{SnCl}_{2}$, heterogeneous $\mathrm{SnCl}_{2} / \mathrm{SiO}_{2}$ proved to be the most effective and significantly higher conversions were achieved compared to $\mathrm{SnCl}_{2} \cdot 2 \mathrm{H}_{2} \mathrm{O}$ itself. The results of TG-DTA and BET indicated that dispersed $\mathrm{SnCl}_{2}$ coordinates with surface hydroxyl groups of silica leading to formation of stable Lewis acid sites. Low catalyst loading, operational simplicity, practicability and applicability to various substrates render this eco-friendly approach as an interesting alternative to previously applied procedures.
\end{abstract}

Key Words: $\mathrm{SnCl}_{2} / \mathrm{SiO}_{2}$, Heterogeneous Lewis acid catalyst, Sustainability, Benzo[N,N]-heterocyclic condensation

\section{Introduction}

Due to the detrimental effects of corrosive protic acids and toxic Lewis acids on the environment and stringent environmental laws and regulations set up by the governments, the use of eco-friendly and reusable heterogeneous solid acid catalysts has increased exponentially in the fine and bulk chemical industries during the last couple of decades. ${ }^{1-3}$

A general trend in catalysis is to transform a successful homogeneous catalyst into a heterogeneous catalytic system. The use of heterogeneous solid catalysts being in a different phase than the reagents and products has an obvious advantage in terms of easy separation from the reaction mixture, allowing the recovery of the solid and eventually its reuse. In addition, a rapidly growing area of heterogeneous catalysis is for environmental pollution control. $^{4-6}$

Among the large number of Lewis acids used in organic synthesis, stannous chloride has not been explored much for its catalytic activity. ${ }^{7-13}$ Even though this homogeneous catalyst shows good catalytic performance, problems related to corrosion, handling, recovery, and reuse of the catalyst set up are limitations of its use in industrial scale.

Solid supports activated with tin salts have received considerable attention in heterogeneous organic reactions in different areas of organic synthesis, ${ }^{14-19}$ not only because it enables environmentally benign synthesis but also due to the good yields accompanied by excellent selectivities that can frequently be achieved.

The benzo $[N, N]$-heterocyclic condensation of 1,2-dicarbonyls with arene-1,2-diamines is an acid-catalyzed reaction. Although, these heterocycles have numerous applications in pharmaceutical and synthetic chemistry, ${ }^{20-26}$ a few catalytic reactions for the preparation of these compounds have been recently reported in the literature. ${ }^{27-35}$ Even though the existing processes have some advantages; most of them suffer from one or more limitations such as the use of homogeneous catalysts, catalyst deactivation, unsatisfactory product yields, cumbersome product isolation and lack of general applicability i.e. inefficiency on low activity substrates. Therefore, development of an efficient and environmentally benign method is still required.

As part of our continuous efforts to develop eco-friendly catalytic processes, ${ }^{36-41}$ herein, we introduce $\mathrm{SnCl}_{2} / \mathrm{SiO}_{2}$ as a novel heterogeneous catalyst for the acid-catalyzed reactions, e.g. benzo $[N, N]$-heterocyclic condensation. The focus of the present study was to provide a fundamental insight into the similarities and differences existing between heterogeneous and homogeneous acid catalyzed condensation.

\section{Results and Discussion}

Characterization of $\mathrm{SnCl}_{2} / \mathrm{SiO}_{2}$ Catalyst. The physical structure of silica gel (high surface area, large pore volume, etc.) is one of the major reasons for its effectiveness as a support material. However, these features can be altered significantly during its chemical modification with inorganic materials. The Brunauer-Emmett-Teller (BET) method determines the dispersion of the active groups and the diffusion of reagents in the active site of silica gel.

Table 1 shows the BET analysis of silica gel and $\mathrm{SnCl}_{2} / \mathrm{SiO}_{2}$. The observed reduction in surface area and pore volume of

Table 1. Textural data of $\mathrm{SiO}_{2}$ and $\mathrm{SnCl}_{2} / \mathrm{SiO}_{2}$

\begin{tabular}{cccc}
\hline Sample & $\begin{array}{c}\text { BET surface } \\
\text { area }\left(\mathrm{m}^{2} / \mathrm{g}\right)\end{array}$ & $\begin{array}{c}\text { Total pore } \\
\text { volume }\left(\mathrm{cm}^{3} / \mathrm{g}\right)\end{array}$ & $\begin{array}{c}\text { Average pore } \\
\text { diameter }(\AA)\end{array}$ \\
\hline $\mathrm{SiO}_{2}$ & 493 & 0.77 & 54 \\
$\mathrm{SnCl}_{2} / \mathrm{SiO}_{2}$ & 244 & 0.55 & 90 \\
\hline
\end{tabular}


(a)

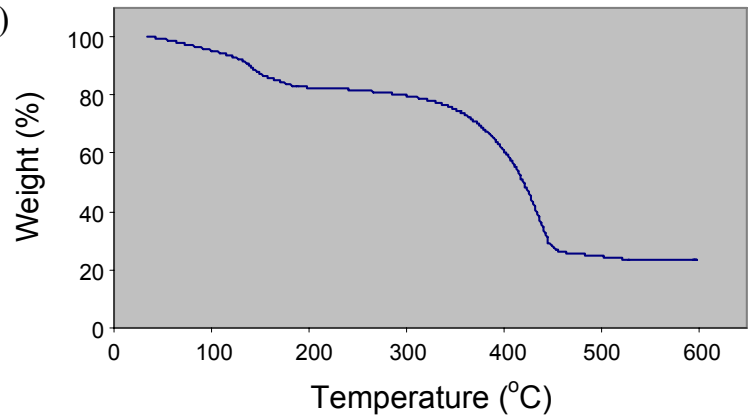

(b)

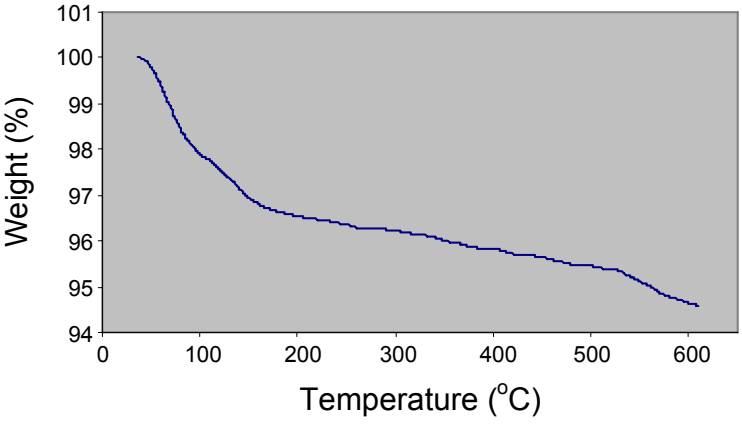

(c)

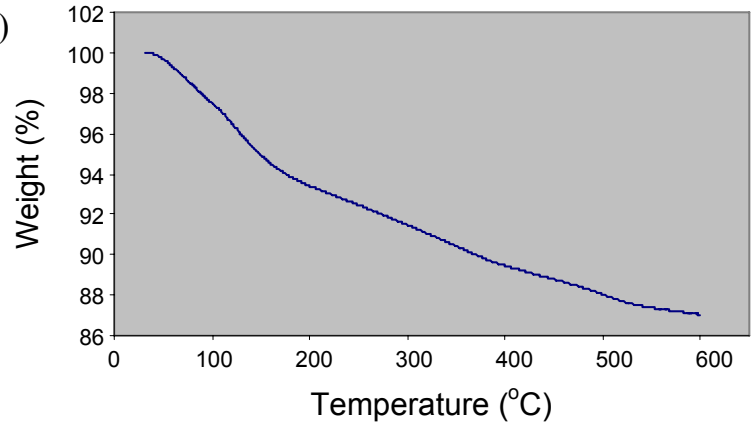

Figure 1. TG-DTA plots of (a) $\mathrm{SnCl}_{2} \cdot 2 \mathrm{H}_{2} \mathrm{O}$, (b) $\mathrm{SiO}_{2}$ activated and (c) $6.6 \% \mathrm{SnCl}_{2} / \mathrm{SiO}_{2}$

$\mathrm{SnCl}_{2} / \mathrm{SiO}_{2}$ as compared to silica gel can be attributed to the surface coverage of silica gel by reagent $\left(\mathrm{SnCl}_{2}\right)$ to define a new modified heterogeneous catalyst.

On the other hand, the thermogravimetric analysis (TGA) gives information on the thermal stability of loaded $\mathrm{SnCl}_{2}$ on silica gel and whether it is chemically bound to the silica surface. As shown in Fig. 1, TG curves of $13 \% \mathrm{SnCl}_{2} / \mathrm{SiO}_{2}$ and $5.4 \% \mathrm{SiO}_{2}$ show a weight loss of around $4 \%$ and $3 \%$ up to $130{ }^{\circ} \mathrm{C}$ which can be attributed to loss of surface physisorbed water. It shows a further weight loss of $9 \%$ and $2.4 \%$ gradually in the range of $130-600{ }^{\circ} \mathrm{C}$ for $\mathrm{SnCl}_{2} / \mathrm{SiO}_{2}$ and $\mathrm{SiO}_{2}$, respectively, which is attributed to the loading of $\mathrm{SnCl}_{2}$ on silica. Accordingly, the exact weight loss of $\mathrm{SnCl}_{2} / \mathrm{SiO}_{2}$ is $6.6 \mathrm{wt} \%$ which is attributed to the formation of $\mathrm{O}-\mathrm{Sn}-\mathrm{Cl}$ species on silica gel with a good agreement with theoretical calculation.

A supporting evidence for the $\mathrm{Sn}$ content of $\mathrm{SnCl}_{2} / \mathrm{SiO}_{2}$ was Atomic Absorption Spectrometry (AAS). It was found to be $5.2 \mathrm{~mol} \%$ which is in good agreement with TGA data.

The proposed structure of the catalyst in which $\mathrm{SnCl}_{2}$ reacted with the surface hydroxyl groups of the silica gel is shown in Fig. 2.

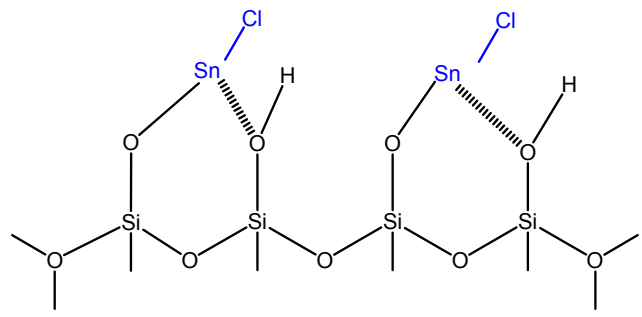

Figure 2. Probable structure of covalently anchored silica-supported stannous chloride.

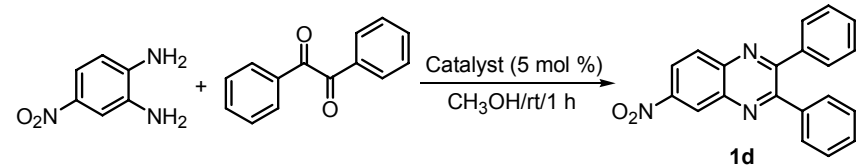

Scheme 1

Table 2. Catalyst screening of homogeneous Lewis acids on the synthesis of $\mathbf{1 d}$

\begin{tabular}{|c|c|c|}
\hline Entry & Catalyst & Conversion $(\%)$ \\
\hline 1 & - & 11 \\
\hline 2 & $\mathrm{SnCl}_{2} \cdot 2 \mathrm{H}_{2} \mathrm{O}$ & 83 \\
\hline 3 & $\mathrm{FeCl}_{3} \cdot 6 \mathrm{H}_{2} \mathrm{O}$ & 75 \\
\hline 4 & $\mathrm{FeCl}_{2} \cdot 4 \mathrm{H}_{2} \mathrm{O}$ & 31 \\
\hline 5 & $\mathrm{Fe}\left(\mathrm{NO}_{3}\right)_{3} \cdot 9 \mathrm{H}_{2} \mathrm{O}$ & 51 \\
\hline 6 & $\mathrm{FeSO}_{4} \cdot 7 \mathrm{H}_{2} \mathrm{O}$ & 32 \\
\hline 7 & $\mathrm{Fe}_{2}\left(\mathrm{SO}_{4}\right)_{3} \cdot \mathrm{xH}_{2} \mathrm{O}$ & 53 \\
\hline 8 & $\mathrm{CuCl}_{2} \cdot 2 \mathrm{H}_{2} \mathrm{O}$ & 78 \\
\hline 9 & $\mathrm{CuCl}_{2}$ & 69 \\
\hline 10 & $\mathrm{CuBr}_{2}$ & 69 \\
\hline 11 & $\mathrm{Cu}\left(\mathrm{NO}_{3}\right)_{2} \cdot 3 \mathrm{H}_{2} \mathrm{O}$ & 64 \\
\hline 12 & $\mathrm{CuSO}_{4} \cdot 5 \mathrm{H}_{2} \mathrm{O}$ & 9 \\
\hline 13 & $\mathrm{CuSO}_{4}$ & 25 \\
\hline 14 & $\mathrm{PdCl}_{2}$ & 18 \\
\hline 15 & $\mathrm{PtCl}_{2}$ & 59 \\
\hline 16 & $\mathrm{CoCl}_{2} \cdot 6 \mathrm{H}_{2} \mathrm{O}$ & 21 \\
\hline 17 & $\mathrm{NiCl}_{2}$ & 28 \\
\hline 18 & $\mathrm{NiSO}_{4} \cdot 6 \mathrm{H}_{2} \mathrm{O}$ & 18 \\
\hline 19 & $\mathrm{ZnCl}_{2}$ & 8 \\
\hline 20 & $\mathrm{HgCl}_{2}$ & 49 \\
\hline 21 & $\mathrm{MnCl}_{2} \cdot 2 \mathrm{H}_{2} \mathrm{O}$ & 36 \\
\hline 22 & $\mathrm{Mn}\left(\mathrm{NO}_{3}\right)_{2} \cdot 4 \mathrm{H}_{2} \mathrm{O}$ & 8 \\
\hline 23 & $\mathrm{MnSO}_{4} \cdot \mathrm{H}_{2} \mathrm{O}$ & 3 \\
\hline
\end{tabular}

Study on Homogeneous Common Lewis Acids as Potential Catalysts. Initially, we examined the condensation of benzil with the less-reactive 4-nitrobenzene-1,2-diamine ${ }^{37}$ to evaluate the efficiency of various metal salts as catalyst (Table 2 ). The reaction was screened in $\mathrm{MeOH}^{42}$ within $1 \mathrm{~h}$ using a catalytic amount of common Lewis acids $(5 \mathrm{~mol} \%$ ) at room temperature (Scheme 1).

The catalytic activity of various Lewis acids was found to be of the order $\mathrm{SnCl}_{2} \cdot 2 \mathrm{H}_{2} \mathrm{O}>\mathrm{CuCl}_{2} \cdot 2 \mathrm{H}_{2} \mathrm{O}>\mathrm{FeCl}_{3} \cdot 6 \mathrm{H}_{2} \mathrm{O}>$ $\mathrm{CuCl}_{2} \approx \mathrm{CuBr}_{2}>\mathrm{Cu}\left(\mathrm{NO}_{3}\right)_{2} \cdot 3 \mathrm{H}_{2} \mathrm{O}>\mathrm{PtCl}_{2}>\mathrm{Fe}_{2}\left(\mathrm{SO}_{4}\right)_{3} \cdot x \mathrm{H}_{2} \mathrm{O}>$ $\mathrm{Fe}\left(\mathrm{NO}_{3}\right)_{3} \cdot 9 \mathrm{H}_{2} \mathrm{O}>\mathrm{HgCl}_{2}$ while the product $1 \mathbf{d}$ was obtained in low and even poor yields when $\mathrm{FeCl}_{2} \cdot 4 \mathrm{H}_{2} \mathrm{O}, \mathrm{FeSO}_{4} \cdot 7 \mathrm{H}_{2} \mathrm{O}$, 
Table 3. Catalyst screening of heterogenous Lewis acid sites on the synthesis of $\mathbf{1 d}$

\begin{tabular}{ccc}
\hline Entry & Catalyst & Conversion $(\%)$ \\
\hline 1 & - & 11 \\
2 & $\mathrm{SnCl}_{2} \cdot 2 \mathrm{H}_{2} \mathrm{O}$ & 83 \\
3 & $\mathrm{SiO}_{2}$ activated & 28 \\
4 & $\mathrm{SnCl}_{2} / \mathrm{SiO}_{2}$ & 98 \\
5 & $\mathrm{SnCl}_{2} / \mathrm{Amberlyst} 15$ & 86 \\
6 & $\mathrm{SnCl}_{2} / \mathrm{Al}_{2} \mathrm{O}_{3}$ acidic & 70 \\
7 & $\mathrm{SnCl}_{2} / \mathrm{Al}_{2} \mathrm{O}_{3}$ neutral & 31 \\
8 & $\mathrm{SnCl}_{2} / \mathrm{Al}_{2} \mathrm{O}_{3}$ basic & 14 \\
\hline
\end{tabular}

$\mathrm{CuSO}_{4} \cdot 5 \mathrm{H}_{2} \mathrm{O}, \mathrm{CuSO}_{4}, \mathrm{PdCl}_{2}, \mathrm{CoCl}_{2} \cdot 6 \mathrm{H}_{2} \mathrm{O}, \mathrm{NiCl}_{2}, \mathrm{NiSO}_{4} \cdot 6 \mathrm{H}_{2} \mathrm{O}$, $\mathrm{ZnCl}_{2}, \mathrm{MnCl}_{2} \cdot 2 \mathrm{H}_{2} \mathrm{O}, \mathrm{Mn}\left(\mathrm{NO}_{3}\right)_{2} \cdot 4 \mathrm{H}_{2} \mathrm{O}$ and $\mathrm{MnSO}_{4} \cdot \mathrm{H}_{2} \mathrm{O}$ were used (Table 2, entries 1-23). Clearly, $\mathrm{SnCl}_{2} \cdot 2 \mathrm{H}_{2} \mathrm{O}$ stands out as the homogeneous Lewis acid catalyst of choice, with its higher conversion.

Optimization of the Model Reaction under Heterogeneous Conditions. In this study, various solid supports activated with $\mathrm{SnCl}_{2}$ were tested for the same reaction (Table 3, entries 4-8). Among them, basic and neutral $\mathrm{Al}_{2} \mathrm{O}_{3}$-supported with $\mathrm{SnCl}_{2}$ showed poor catalytic activities, whereas $\mathrm{SnCl}_{2} / \mathrm{SiO}_{2}$ could efficiently catalyze the reaction to afford the desired product in high yield even better than $\mathrm{SnCl}_{2} \cdot 2 \mathrm{H}_{2} \mathrm{O}$ itself. As regards the silica gel alone, there was a poor activity for the reaction (Table 3, entry 3 ).

Therefore, the remarkable efficiency of $\mathrm{SnCl}_{2} / \mathrm{SiO}_{2}$ can be explained by a better synergetic effect of $\mathrm{SnCl}_{2}$ with $\mathrm{SiO}_{2}$, due to the existence of multiple Lewis acid catalytic centers (Fig. 2).

There are recent reports of carrying out this reaction in the presence of other catalysts under similar conditions (Table 4). It is evident from the results that, $\mathrm{SnCl}_{2} / \mathrm{SiO}_{2}$ stands for an improved protocol in terms of reaction time and yield when compared with the other catalysts.

Evaluation of the Reaction Scope. To evaluate the scope of catalyst's application, various arene-1,2-diamines were tested with 1,2-dicarbonyls under the optimized conditions and the results are presented in Table 5. In all cases, the reactions proceeded expeditiously at room temperature, although the yields were highly dependent on the substrate used (Table 5).

Turnover frequency (TOF) as a measure of catalyst activity for this catalytic process has been compared in Table 5 to show the reaction rate is highly dependent on the substrate used. In most cases, high values of TOF in range of $40-600 \mathrm{~h}^{-1}$ have

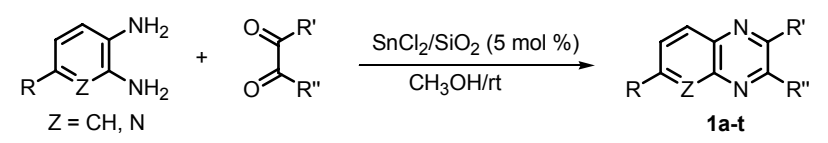

Scheme 2

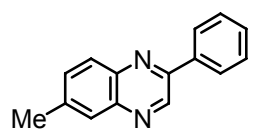

$1 q$

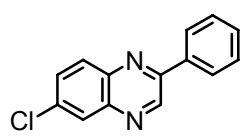

$1 \mathrm{r}$

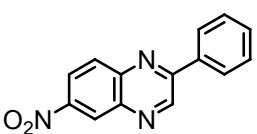

1s
Figure 3. The major isomer of the 6-/7-substituted products as determined by ${ }^{1} \mathrm{H}$ NMR spectroscopy.

been achieved. A typical example of very low TOF value is for $\mathbf{1 i}\left(4 \mathrm{~h}^{-1}\right)$ which is resulted from the two less-reactive substrates in this condensation reaction. ${ }^{36-39,43-44}$

The regioselectivity for 4-substituted 1,2-diaminobenzenes on treatment with phenylglyoxal in the presence of $\mathrm{SnCl}_{2} / \mathrm{SiO}_{2}$ was also investigated (Table 5, entries 17-20). With the exception of 2,3-diaminopyridine, which showed very high selectivity to cis-regioisomer $\mathbf{1 t},{ }^{45-46}$ the condensation of other 4-substituted 1,2-diaminobenzenes with phenylglyoxal resulted in a mixture of regioisomers 1q-1s, in favor of trans-regioisomers ${ }^{47-49}$ (Fig. 3). The regioselectivity was determined by ${ }^{1} \mathrm{H}$ NMR and also by comparison with known samples.

Recycling of $\mathrm{SnCl}_{2} / \mathrm{SiO}_{2}$. The feasibility of repeated use of $\mathrm{SnCl}_{2} / \mathrm{SiO}_{2}$ was also examined. The recovery of catalyst was very easy. After completion of the reaction $\mathrm{CH}_{3} \mathrm{OH}$ was removed under reduced pressure and $\mathrm{CH}_{2} \mathrm{Cl}_{2}$ was added. Product is soluble in $\mathrm{CH}_{2} \mathrm{Cl}_{2}$, while the catalyst remains insoluble. The catalyst was simply filtered from the reaction mixture, dried at $120{ }^{\circ} \mathrm{C}$ for $2 \mathrm{~h}$ and reused in subsequent run (Fig. 3). No fresh catalyst was added. The catalyst was thus tested for 4 runs for products 1a and 1d, possessing high and low TOF, respectively. The reaction proceeded smoothly with the yields of $96-100 \%$ for $1 \mathrm{a}$ within $4 \mathrm{~min}$ and 70 - 94\% for $\mathbf{1 d}$ within $1 \mathrm{~h}$ (Fig. 4). For high TOF 1a, the catalytic activity of $\mathrm{SnCl}_{2} / \mathrm{SiO}_{2}$ in terms of yields slightly decreased with increasing number of cycles of the reaction, whereas the decrease of catalytic activity of $\mathrm{SnCl}_{2} /$ $\mathrm{SiO}_{2}$ for low TOF $1 \mathrm{~d}$ upon each recycling was quite sizeable.

To test the activity of the catalyst on large-scale, a series of 4 consecutive runs were carried out for the condensation of benzene-1,2-diamine and benzil ( $55: 50 \mathrm{mmol})$. The results of

Table 4. Literature results for the synthesis of $\mathbf{1 d}$ at ambient temperature

\begin{tabular}{|c|c|c|c|c|c|}
\hline Entry & Catalyst & Solvent & Reaction time (h) & Isolated Yield (\%) & [Ref] \\
\hline 1 & Polyaniline-sulfate $(5 \% \mathrm{w} / \mathrm{w})$ & $\mathrm{ClCH}_{2} \mathrm{CH}_{2} \mathrm{Cl}$ & 0.7 & 90 & {$[30]$} \\
\hline 2 & Montmorillonite K-10 $(10 \% \mathrm{w} / \mathrm{w})$ & $\mathrm{H}_{2} \mathrm{O}$ & 6 & 70 & [33] \\
\hline 3 & Gallium triflate $(1 \mathrm{~mol} \%)$ & $\mathrm{C}_{2} \mathrm{H}_{5} \mathrm{OH}$ & 6 & 90 & [34] \\
\hline 4 & $\mathrm{ZrO}_{2}(17 \%) / \mathrm{Ga}_{2} \mathrm{O}_{3}(4 \%) / \mathrm{MCM}-41$ & $\mathrm{CH}_{3} \mathrm{CN}$ & 2 & 91 & {$[35]$} \\
\hline 5 & Zirconium tetrachloride (5 mol \%) & $\mathrm{CH}_{3} \mathrm{OH}$ & 4 & 98 & {$[36]$} \\
\hline 6 & $\mathrm{SbCl}_{3} / \mathrm{SiO}_{2}(2.5 \mathrm{~mol} \%)$ & $\mathrm{CH}_{3} \mathrm{OH}$ & 1 & 92 & [37] \\
\hline 7 & Ammonium chloride (200 $\mathrm{mol} \%)$ & $\mathrm{CH}_{3} \mathrm{OH}$ & 4 & 66 & {$[38]$} \\
\hline 8 & Sulfamic acid $(80 \mathrm{~mol} \%)$ & $\mathrm{CH}_{3} \mathrm{OH}$ & 5 & 95 & [39] \\
\hline 9 & $\mathrm{SnCl}_{2} / \mathrm{SiO}_{2}(5 \mathrm{~mol} \%)$ & $\mathrm{CH}_{3} \mathrm{OH}$ & 1 & 94 & This work \\
\hline
\end{tabular}


Table 5. Evaluation of reaction scope

\begin{tabular}{cccccccccc}
\hline Entry & $\mathrm{R}$ & $\mathrm{R}$ & $\mathrm{R}$ & $\mathrm{Z}$ & Product & Time & Conversion $(\%)$ & $\mathrm{Yield}^{\prime}(\%)^{a}$ & $\left.\mathrm{TOF}^{-1}\right)^{b}$ \\
\hline 1 & $\mathrm{H}$ & $\mathrm{Ph}$ & $\mathrm{Ph}$ & $\mathrm{CH}$ & $\mathbf{1 a}$ & $4 \mathrm{~min}$ & 100 & 100 & 300 \\
2 & $\mathrm{Me}$ & $\mathrm{Ph}$ & $\mathrm{Ph}$ & $\mathrm{CH}$ & $\mathbf{1 b}$ & $3 \mathrm{~min}$ & 100 & 99 & 400 \\
3 & $\mathrm{Cl}$ & $\mathrm{Ph}$ & $\mathrm{Ph}$ & $\mathrm{CH}$ & $\mathbf{1 c}$ & $10 \mathrm{~min}$ & 100 & 96 & 120 \\
4 & $\mathrm{NO}_{2}$ & $\mathrm{Ph}$ & $\mathrm{Ph}$ & $\mathrm{CH}$ & $\mathbf{1 d}$ & $1 \mathrm{~h}$ & 98 & 94 & 20 \\
5 & $\mathrm{H}$ & $\mathrm{Ph}$ & $\mathrm{Ph}$ & $\mathrm{N}$ & $\mathbf{1 e}$ & $45 \mathrm{~min}$ & 100 & 96 & 27 \\
6 & $\mathrm{H}$ & $4-(\mathrm{MeO})-\mathrm{Ph}$ & $4-(\mathrm{MeO})-\mathrm{Ph}$ & $\mathrm{CH}$ & $\mathbf{1 f}$ & $30 \mathrm{~min}$ & 100 & 98 & 40 \\
7 & $\mathrm{Me}$ & $4-(\mathrm{MeO})-\mathrm{Ph}$ & $4-(\mathrm{MeO})-\mathrm{Ph}$ & $\mathrm{CH}$ & $\mathbf{1 g}$ & $25 \mathrm{~min}$ & 100 & 98 & 48 \\
8 & $\mathrm{Cl}$ & $4-(\mathrm{MeO})-\mathrm{Ph}$ & $4-(\mathrm{MeO})-\mathrm{Ph}$ & $\mathrm{CH}$ & $\mathbf{1 h}$ & $1 \mathrm{~h}$ & 100 & 97 & 20 \\
9 & $\mathrm{NO}$ & $4-(\mathrm{MeO})-\mathrm{Ph}$ & $4-(\mathrm{MeO})-\mathrm{Ph}$ & $\mathrm{CH}$ & $\mathbf{1 i}$ & $4 \mathrm{~h}$ & 88 & 76 & 4 \\
10 & $\mathrm{H}$ & $4-(\mathrm{MeO})-\mathrm{Ph}$ & $4-(\mathrm{MeO})-\mathrm{Ph}$ & $\mathrm{N}$ & $\mathbf{1 j}$ & $3 \mathrm{~h}$ & 98 & 94 & 7 \\
11 & $\mathrm{H}$ & $\mathrm{Me}$ & $\mathrm{Me}$ & $\mathrm{CH}$ & $\mathbf{1 k}$ & $2 \mathrm{~min}$ & 100 & 99 & 600 \\
12 & $\mathrm{Me}$ & $\mathrm{Me}$ & $\mathrm{Me}$ & $\mathrm{CH}$ & $\mathbf{1 l}$ & $2 \mathrm{~min}$ & 100 & 99 & 600 \\
13 & $\mathrm{Cl}$ & $\mathrm{Me}$ & $\mathrm{Me}$ & $\mathrm{CH}$ & $\mathbf{1 m}$ & $5 \mathrm{~min}$ & 100 & 96 & 240 \\
14 & $\mathrm{NO}_{2}$ & $\mathrm{Me}$ & $\mathrm{Me}$ & $\mathrm{CH}$ & $\mathbf{1 n}$ & $30 \mathrm{~min}$ & 100 & 96 & 40 \\
15 & $\mathrm{H}$ & $\mathrm{Me}$ & $\mathrm{Me}$ & $\mathrm{N}$ & $\mathbf{1 0}$ & $10 \mathrm{~min}$ & 100 & 95 & 120 \\
16 & $\mathrm{H}$ & $\mathrm{Ph}$ & $\mathrm{H}$ & $\mathrm{CH}$ & $\mathbf{1 p}$ & $5 \mathrm{~min}$ & 100 & 99 \\
17 & $\mathrm{Me}$ & $\mathrm{Ph}$ & $\mathrm{H}$ & $\mathrm{CH}$ & $\mathbf{1 q}$ & $5 \mathrm{~min}$ & 100 & $99^{c}(73 / 27)^{d}$ & 240 \\
18 & $\mathrm{Cl}$ & $\mathrm{Ph}$ & $\mathrm{H}$ & $\mathrm{CH}$ & $\mathbf{1 r}$ & $7 \mathrm{~min}$ & 100 & $98^{c}(65 / 35)^{d}$ & 171 \\
19 & $\mathrm{NO}_{2}$ & $\mathrm{Ph}$ & $\mathrm{H}$ & $\mathrm{CH}$ & $\mathbf{1 s}$ & $10 \mathrm{~min}$ & 100 & $95^{c}(82 / 18)^{d}$ & 120 \\
20 & $\mathrm{H}$ & $\mathrm{Ph}$ & $\mathrm{H}$ & $\mathrm{N}$ & $\mathbf{1 t}$ & $5 \mathrm{~min}$ & 100 & $93^{e}$ & 240 \\
\hline
\end{tabular}

${ }^{a}$ Yields refer to those of pure isolated products characterized by ${ }^{1} \mathrm{H} \mathrm{NMR},{ }^{13} \mathrm{C}$ NMR and MS spectral analyses which is consistent with literature values. ${ }^{b}$ TOF: Turnover frequency $=$ moles of converted substrate (1,2-dicarbonyl) $/\left(\right.$ moles of $\mathrm{SnCl}_{2} \times$ reaction time in $\left.\mathrm{h}\right){ }^{c}$ Isolated as a mixture of two regioisomers i.e. 6-/7-substituted-2-phenylquinoxalines. ${ }^{d}$ Ratio of the 6-/7-substituted products as determined by ${ }^{1} \mathrm{H}$ NMR spectroscopy. ${ }^{e} 3$-phenylpyrido[2,3- $b]$ pyrazine is formed as a sole regioisomer.

Table 6. Evaluation of catalyst leaching

\begin{tabular}{ccc}
\hline Run & Decreased weight $(\%)^{a}$ & Isolated Yield (\%) \\
\hline 1st & 7.08 & 98 \\
2nd & 9.00 & 95 \\
3rd & 12.27 & 87 \\
4th & 13.83 & 85
\end{tabular}

${ }^{a}$ From 150 to $800{ }^{\circ} \mathrm{C}$.
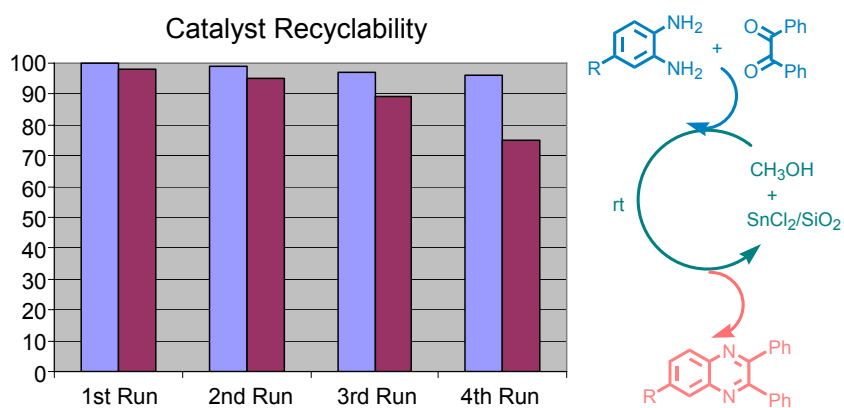

Figure 4. Effect of reuse of catalyst on high TOF 1a and low TOF $1 \mathbf{d}$.

both the thermogravimetric analysis of the catalyst and isolated yield of 2,3-diphenylquinoxaline 1a after each run are shown in Table 6. These results demonstrate that there is a decrease in the activity of the catalyst after every use. This may be due to deactivation of active centers resulting from complexation with both starting materials and products.

\section{Conclusion}

Silica-supported stannous chloride is prepared and characterized as a heterogeneous Lewis acid catalyst. In an example, it shows high efficiency for the synthesis of a variety of benzo $[N, N]$-heterocycles in excellent yields at room temperature. The experiments show that Lewis acid sites on $\mathrm{SnCl}_{2} / \mathrm{SiO}_{2}$ catalyst are the active sites for the reaction. While the reactions provide the products in high to excellent selectivities, the products, in most cases, were obtained in excellent yields $(>98 \%)$ in very short reaction times.

From the environmental standpoint, this eco-friendly catalyst possesses advantages of ease of preparation and handling, long shelf life i.e. high stability and excellent activity. Moreover, the catalyst could be successfully recovered and recycled at least for four runs even in case of low activity starting materials.

\section{Experimental}

Materials and Methods. The $\mathrm{N}_{2}$ adsorption/desorption analyses were performed on BELSORP-miniII at $77 \mathrm{~K}$. Silica gel was degassed at $300{ }^{\circ} \mathrm{C}$ for $1.5 \mathrm{~h}$ but $\mathrm{SnCl}_{2} / \mathrm{SiO}_{2}$ was degassed at $100{ }^{\circ} \mathrm{C}$ for $1.5 \mathrm{~h}$ under inert gas flow prior analysis. Specific surface area, total pore volume, and pore diameter of samples was obtained by Brunauer-Emmett-Teller (BET) method using BELSORP analysis software. Thermogravimetric analysis (TGA) measurements of silica gel and $\mathrm{SnCl}_{2} / \mathrm{SiO}_{2}$ were carried out in PerkinElmer Pyris Diamond instrument from 32 to $600{ }^{\circ} \mathrm{C}$, using a ramp rate of $10^{\circ} \mathrm{C} / \mathrm{min}$ under dry $\mathrm{N}_{2}$. The Sn content was also 
determined by Atomic Absorption Spectrophotometer (AASPerkin-Elmer 1100) using a flame approach, after acid dissolution of known amount of the silica material.

${ }^{1} \mathrm{H}$ and ${ }^{13} \mathrm{C}$ NMR spectra were recorded on a Bruker-500. All NMR samples were run in $\mathrm{CDCl}_{3}$ and chemical shifts are expressed as ppm relative to internal $\mathrm{Me}_{4} \mathrm{Si}$. Mass spectra were obtained on a Fisons instrument. Substrates are commercially available and used without further purification.

Preparation of $\mathrm{SnCl}_{2} / \mathrm{SiO}_{2}$ Catalyst. $30 \mathrm{~g}$ of silica gel (300 $400 \mathrm{mesh}$ ) were activated by refluxing with $150 \mathrm{~mL}$ of $6 \mathrm{~mol} \cdot \mathrm{L}^{-1}$ hydrochloric acid under stirring for $24 \mathrm{~h}$, then the activated silica gel was filtered and washed with doubly distilled water to neutral and dried under vacuum at $70{ }^{\circ} \mathrm{C}$ for $24 \mathrm{~h} .{ }^{50}$

Stannous chloride dihydrate $(2.25 \mathrm{~g})$ was added to a suspension of activated silica gel $(27.75 \mathrm{~g})$ in EtOH $(50.0 \mathrm{~mL})$. The mixture was stirred at room temperature overnight. Then the solvent was removed under reduced pressure and the residue was heated at $100{ }^{\circ} \mathrm{C}$ under vacuum for $5 \mathrm{~h}$ to furnish $\mathrm{SnCl}_{2} /$ $\mathrm{SiO}_{2}$ as a white free-flowing powder $(6.6 \mathrm{wt} \%$ of $\mathrm{O}-\mathrm{Sn}-\mathrm{Cl}$ species as determined by TGA and $5.2 \mathrm{~mol} \%$ of Sn as determined by AAS).

General Procedure for the Acid-catalyzed Benzo[ $N, N]$-heterocyclic Condensation. A mixture of arene-1,2-diamine (1.1 mmol), 1,2-dicarbonyl (1 mmol), and $0.30 \mathrm{~g}$ of $\mathrm{SnCl}_{2} / \mathrm{SiO}_{2}$ $(5 \mathrm{~mol} \%)$ was taken in methanol $(5 \mathrm{~mL})$ and stirred at room temperature for the appropriate reaction time (Table 5). After completion of the reaction (monitored by TLC using ethyl acetate/hexane $(3: 7 \mathrm{v} / \mathrm{v})$ or $\mathrm{GC})$, the organic medium was removed with rotary evaporator under reduced pressure. Dichloromethane $(10 \mathrm{~mL})$ was added to the resulting solid mixture. The catalyst was recovered by filtration and the $\mathrm{CH}_{2} \mathrm{Cl}_{2}$ was evaporated to afford the product $\mathbf{1}$. For analytical measurements, the crude products were crystallized from ethanol to afford pure products. The identification of the isolated products was generally performed by ${ }^{1} \mathrm{H} \mathrm{NMR},{ }^{13} \mathrm{C}$ NMR and MS spectral analyses.

\section{Selected Spectroscopic Data.}

6-Chloro-2,3-diphenylquinoxaline (1c): ${ }^{51} \mathrm{mp} 122$ - $124{ }^{\circ} \mathrm{C}$; ${ }^{1} \mathrm{H}$ NMR $\left(500 \mathrm{MHz}, \mathrm{CDCl}_{3}\right) \delta 7.36(\mathrm{~m}, 6 \mathrm{H}), 7.53(\mathrm{~d}, 4 \mathrm{H}), 7.69$ $(\mathrm{dd}, 1 \mathrm{H}), 8.10(\mathrm{~d}, 1 \mathrm{H}), 8.17(\mathrm{~d}, 1 \mathrm{H}) ;{ }^{13} \mathrm{C} \mathrm{NMR}\left(125 \mathrm{MHz}, \mathrm{CDCl}_{3}\right)$ $\delta 128.32,128.52,128.76(2 \mathrm{C}), 129.46,129.54,130.25,130.31$, $130.69,130.89,131.30,131.46,136.08,136.11,139.11,139.18$, $140.16,141.92,154.04,154.71$; MS (EI), $m / z$ (rel. intensity \%) $316\left(\mathrm{M}^{+}, 100\right), 279$ (10), 239 (10), 213 (25), 177 (55), 103 (85), $75(70)$.

2,3-Bis(4-methoxyphenyl)quinoxaline (1f): ${ }^{36} \mathrm{mp} 152$ - 153 ${ }^{\circ} \mathrm{C}$; ${ }^{1} \mathrm{H}$ NMR $\left(500 \mathrm{MHz}, \mathrm{CDCl}_{3}\right) \delta 3.88(\mathrm{~s}, 6 \mathrm{H}), 6.92(\mathrm{~d}, 4 \mathrm{H})$, 7.54 (d, 4H), $7.76(\mathrm{dd}, 2 \mathrm{H}), 8.17$ (dd, $2 \mathrm{H}) ;{ }^{13} \mathrm{C}$ NMR (125 MHz, $\left.\mathrm{CDCl}_{3}\right) \delta 55.74,114.21,129.45,129.95,131.70,132.18,141.51$, 153.45, 160.61; MS (EI), $m / z$ (rel. intensity \%) $342\left(\mathrm{M}^{+}, 100\right)$, 328 (45), 312 (45), 209 (40), 166 (50).

6-Chloro-2,3-bis(4-methoxyphenyl)quinoxaline (1h): ${ }^{29} \mathrm{mp}$ $151-152{ }^{\circ} \mathrm{C} ;{ }^{1} \mathrm{H}$ NMR $\left(500 \mathrm{MHz}, \mathrm{CDCl}_{3}\right) \delta 3.83(\mathrm{~s}, 6 \mathrm{H}), 6.87$ $(\mathrm{d}, 4 \mathrm{H}), 7.49(\mathrm{dd}, 4 \mathrm{H}), 7.64(\mathrm{dd}, 1 \mathrm{H}), 8.03(\mathrm{~d}, 1 \mathrm{H}), 8.10(\mathrm{~d}, 1 \mathrm{H})$; ${ }^{13} \mathrm{C} \mathrm{NMR}\left(125 \mathrm{MHz}, \mathrm{CDCl}_{3}\right) \delta 55.71,55.79,114.20,114.30$, $128.10,128.29,128.33,128.52,130.63,130.68,130.80,130.95$, $131.71,131.77,131.80,135.54,139.97,141.75,153.58,154.23$, 160.77, 160.85; MS (EI), $m / z$ (rel. intensity \%) $376\left(\mathrm{M}^{+}, 100\right)$, 361 (30), 345 (35), 243 (25), 133 (65), 103(30).
2,3-Dimethylquinoxaline (1k): ${ }^{38} \mathrm{mp} 103-104{ }^{\circ} \mathrm{C} ;{ }^{1} \mathrm{H}$ NMR $\left(500 \mathrm{MHz}, \mathrm{CDCl}_{3}\right) \delta 2.78(\mathrm{~s}, 6 \mathrm{H}), 7.70(\mathrm{dd}, 2 \mathrm{H}), 8.02(\mathrm{dd}, 2 \mathrm{H})$; ${ }^{13} \mathrm{C}$ NMR $\left(125 \mathrm{MHz}, \mathrm{CDCl}_{3}\right) \delta 23.76,128.7,129.2,141.5$, 153.9; MS (EI), $m / z$ (rel. intensity \%) $158\left(\mathrm{M}^{+}, 65\right), 116(100)$, 76 (40), 50 (50).

6-Chloro-2,3-dimethylquinoxaline (1m): ${ }^{38} \mathrm{mp} 89-91{ }^{\circ} \mathrm{C} ;{ }^{1} \mathrm{H}$ $\operatorname{NMR}\left(500 \mathrm{MHz}, \mathrm{CDCl}_{3}\right) \delta 2.76(\mathrm{~s}, 3 \mathrm{H}), 2.77(\mathrm{~s}, 3 \mathrm{H}), 7.64(\mathrm{dd}$, $1 \mathrm{H}), 7.93(\mathrm{~d}, 1 \mathrm{H}), 8.00(\mathrm{~d}, 1 \mathrm{H}) ;{ }^{13} \mathrm{C} \mathrm{NMR}\left(125 \mathrm{MHz}, \mathrm{CDCl}_{3}\right) \delta$ 23.5, 23.6, 127.8, 130.0, 130.2, 134.8, 140.0, 141.8, 154.2, 154.9; MS (EI), $m / z$ (rel. intensity \%) $192\left(\mathrm{M}^{+}, 70\right), 151$ (100), $110(60), 75$ (65).

6-/7-Methyl-2-phenylquinoxaline (1q): ${ }^{47} \mathrm{H} \mathrm{NMR}(500 \mathrm{MHz}$, $\left.\mathrm{CDCl}_{3}\right) \delta\{[9.29$ (s, cis isomer): 9.27 (s, trans isomer)] (27 : 73) $(1 \mathrm{H}, 3-H)\}, 8.18-8.21(\mathrm{dd}, 2 \mathrm{H}, P h), 7.89-8.07$ (m, 2H, 5-H and 8-H), 7.50-7.64 (m, 4H, 7-H and $P h), 2.62(\mathrm{~s}, 3 \mathrm{H}, M e)$; ${ }^{13} \mathrm{C} \mathrm{NMR}\left(125 \mathrm{MHz}, \mathrm{CDCl}_{3}\right) \delta 151.61,150.90,143.18,142.39$, $142.28,141.57,140.72,140.67,140.01,136.85,132.54,131.80$, 130.03, 129.93, 129.07, 128.57, 128.43, 127.9, 127.95, 127.46, 127.37, 29.75, 21.87; MS (EI), $m / z$ (rel. intensity \%) $220\left(\mathrm{M}^{+}\right.$, 100), 193 (15), 165 (10), 116 (5), 104 (5), 89 (20), 77 (10), 63 (12).

6-/7-Chloro-2-phenylquinoxaline (1r): ${ }^{48} \mathrm{H}$ NMR (500 MHz, $\left.\mathrm{CDCl}_{3}\right) \delta\{[9.31$ (s, cis isomer): 9.30 (s, trans isomer)] (35 : 65) $(1 \mathrm{H}, 3-H)\}, 8.18(\mathrm{~d}, 2 \mathrm{H}, P h), 8.03-8.14(\mathrm{~m}, 2 \mathrm{H}, 5-H$ and 8-H), 7.66-7.72 (m, 1H, 7-H), 7.51-7.58 (m, 3H, Ph); ${ }^{13} \mathrm{C}$ NMR $\left(125 \mathrm{MHz}, \mathrm{CDCl}_{3}\right) \delta 152.96,152.36,144.57,143.85$, $143.08,140.53,136.73,136.52,135.67,131.75,131.27,130.99$, 130.94, 130.87, 130.78, 129.65, 128.93, 128.51, 128.04, 127.94, 77.71, 77.46, 77.21; MS (EI), $m / z$ (rel. intensity \%) $240\left(\mathrm{M}^{+}\right.$, 100), 213 (12), 178 (15), 151 (5), 110 (7), 77 (10), 50 (12).

6-Nitro-2-phenylquinoxaline (1s): ${ }^{49}{ }^{1} \mathrm{H}$ NMR $(500 \mathrm{MHz}$, $\left.\mathrm{CDCl}_{3}\right) \delta 9.49(\mathrm{~s}, 1 \mathrm{H}), 9.02(\mathrm{~d}, 1 \mathrm{H}, J 2.0 \mathrm{~Hz}, 5-H), 8.55(\mathrm{dd}$, $1 \mathrm{H}, J 2.0 \mathrm{~Hz}, J 9.2 \mathrm{~Hz}, 7-H), 8.27(\mathrm{~m}, 3 \mathrm{H}, 8-H$ and $P h), 7.60$ $(\mathrm{d}, 3 \mathrm{H}, \mathrm{Ph}) ;{ }^{13} \mathrm{C}$ NMR $\left(125 \mathrm{MHz}, \mathrm{CDCl}_{3}\right) \delta 154.75,147.88$, 145.92, 145.35, 140.78, 136.06, 131.83, 131.61, 129.85, 128.37, $128.18,126.10,124.21,123.25 ; \mathrm{MS}(\mathrm{EI}), \mathrm{m} / z$ (rel. intensity \%) $251\left(\mathrm{M}^{+}, 100\right), 224$ (5), 205 (10), 178 (10), 151 (4), 104 (5), 75 (7), $50(5)$

3-Phenylpyrido[2,3-b]pyrazine (1t): ${ }^{.5-46}{ }^{1} \mathrm{H} \mathrm{NMR}(500 \mathrm{MHz}$, $\left.\mathrm{CDCl}_{3}\right) \delta 9.46(\mathrm{~s}, 1 \mathrm{H}, 2-H) 9.19(\mathrm{dd}, 1 \mathrm{H}, 6-H), 8.47(\mathrm{dd}, 1 \mathrm{H}$, $8-H), 8.35(\mathrm{dd}, 2 \mathrm{H}, P h), 7.70(\mathrm{dd}, 1 \mathrm{H}, 7-H), 7.56(\mathrm{~m}, 3 \mathrm{H}) ;{ }^{13} \mathrm{C}$ NMR $\left(125 \mathrm{MHz}, \mathrm{CDCl}_{3}\right) \delta 154.65,154.49,150.86,144.34$, $138.17,136.79,135.72,131.03,129.19,128.05,124.75 ; \mathrm{MS}$ (EI), $m / z$ (rel. intensity \%) $207\left(\mathrm{M}^{+}, 100\right), 179$ (20), 153 (5), 104 (25), 77 (15), 50 (20).

\section{References}

1. Corma, A. Chem. Rev. 1995, 95, 559-614.

2. Wilson, K.; Clark, J. H. Pure Appl. Chem. 2000, 72, 1313-1319.

3. Okuhara, T. Chem. Rev. 2002, 102, 3641-3666.

4. Clark, J. H. Acc. Chem. Res. 2002, 35, 791-797.

5. Corma, A.; Garcia, H. Chem. Rev. 2003, 103, 4307-4365.

6. Sartori, G.; Ballini, R.; Bigi, F.; Bosica, G.; Maggi, R.; Righi, P. Chem. Rev. 2004, 104, 199-250.

7. Russowsky, D.; Lopes, F. A.; da Silva, V. S. S.; Canto, K. F. S.; Montes D’Oca, M. G.; Godoi, M. N. J. Braz. Chem. Soc. 2004, 15, 165-169.

8. Arumugam, P.; Karthikeyan, G.; Atchudan, R.; Muralidharan, D.; 
Perumal, P. T. Chem. Lett. 2005, 34, 314-315.

9. Alam, M. M.; Varala, R.; Enugala, R.; Adapa, S. R. Lett. Org. Chem. 2006, 3, 187-190.

10. Nagarapu, L.; Bantu, R.; Puttireddy, R. Appl. Catal. A: Gen. 2007, 332, 304-309.

11. Upadhyay, K. K.; Mishra, R. K.; Kumar, A. Catal Lett. 2008, 121, $118-120$.

12. Azarifar, D.; Khosravi, K.; Soleimanei, F. Synthesis 2009, $2553-$ 2556.

13. Selvam, N. P.; Babu, T. H.; Perumal, P. T. Tetrahedron 2009, 65, 8524-8530.

14. Corma, A.; Domine, M. E.; Valencia, S. J. Catal. 2003, 215, 304.

15. Endud, S.; Wong, K-L. Micropor. Mesopor. Mater. 2007, 101, 256-263.

16. Fan, B.; Zhang, J.; Li, R.; Fan, W. Catal. Lett. 2008, 121, 297-302.

17. Taralkar, U. S.; Kalita, P.; Kumar, R.; Joshi, P. N. Appl. Catal. A: Gen. 2009, 358, 88-94.

18. Fan, B.; Li, H.; Fan, W.; Zhang, J.; Li, R. Appl. Catal. A: Gen. 2010, 372, 94-102

19. Selvaraj, M.; Choe, Y. Appl. Catal. A: Gen. 2010, 373, 186-191.

20. Urleb, U. In: Schaumann, E. (Ed.): Methods of Organic Chemistry (Houben-Weyl); Thieme: Stuttgart, New York, 1998, Vol. E9b / Part 2 (Hetarenes IV), pp 193-265.

21. Sako, M. In: Yamamoto, Y. (Volume Ed.): Science of Synthesis: Houben-Weyl Methods of Molecular Transformations; Thieme: Stuttgart, New York, 2003, Vol. 16, pp 1269-1290.

22. Martins, M. A. P.; Frizzo, C. P.; Moreira, D. N.; Buriol, L.; Machado, P. Chem. Rev. 2009, 109, 4140-4182.

23. Candeias, N. R.; Branco, L. C.; Gois, P. M. P.; Afonso, C. A. M.; Trindade, A. F. Chem. Rev. 2009, 109, 2703-2802.

24. Corona, P.; Carta, A.; Loriga, M.; Vitale, G.; Paglietti, G. Eur. J. Med. Chem. 2009, 44, 1579-1591.

25. Carta, A.; Piras, S.; Loriga, G.; Paglietti, G. Mini-Rev. Med. Chem. 2006, 6, 1179-1200.

26. Yeo, B. R.; Hallett, A. J.; Kariuki, B. M.; Pope, S. J. A. Polyhedron 2010, 29, 1088-1094.

27. More, S. V.; Sastry, M. N. V.; Wang, C-C.; Yao, C-F. Tetrahedron Lett. 2005, 46, 6345-6348.

28. Bhosale, R. S.; Sarda, S. R.; Ardhapure, S. S.; Jadhav, W. N.; Bhusare, S. R.; Pawar, R. P. Tetrahedron Lett. 2005, 46, 71837186.

29. More, S. V.; Sastry, M. N. V.; Yao, C-F. Green Chem. 2006, 8, 91-95.

30. Srinivas, C.; Kumar, C. N. S. S. P.; Jayathirtha Rao, V.; Palaniappan, S. J. Mol. Catal. A: Chem. 2007, 265, 227-230.
31. Dong, F.; Kai, G.; Zhenghao, F.; Xinli, Z.; Zuliang, L. Catal. Commun. 2008, 9, 317-320.

32. Kumar, A.; Kumar, S.; Saxena, A.; De, A.; Mozumdar, S. Catal. Commun. 2008, 9, 778-784.

33. Huang, T-K.; Wang, R.; Shi, L.; Lu, X-X. Catal. Commun. 2008, 9, 1143-1147.

34. Cai, J. J.; Zou, J. P.; Pan, X. Q.; Zhang, W. Tetrahedron Lett. 2008, 49, 7386-7390

35. Ajaikumar, S.; Pandurangan, A. Appl. Catal. A: Gen. 2009, 357, 184-192.

36. Aghapoor, K.; Darabi, H. R.; Mohsenzadeh, F.; Balavar, Y.; Daneshyar, H. Transit. Metal Chem. 2010, 35, 49-53.

37. Darabi, H. R.; Aghapoor, K.; Mohsenzadeh, F.; Taala, F.; Asadollahnejad, N.; Badiei, A. Catal. Lett. 2009, 133, 84-89.

38. Darabi, H. R.; Tahoori, F.; Aghapoor, K.; Taala, F.; Mohsenzadeh, F. J. Braz. Chem. Soc. 2008, 19, 1646-1652.

39. Darabi, H. R.; Mohandessi, S.; Aghapoor, K.; Mohsenzadeh, F. Catal. Commun. 2007, 8, 389-392.

40. Mohsenzadeh, F.; Aghapoor, K.; Darabi, H. R. J. Braz. Chem. Soc. 2007, 18, 297-303.

41. Aghapoor, K.; Darabi, H. R.; Mohsenzadeh, F. Z. Naturforsch. 2005, 60b, 901-903.

42. According to the "solvent selection tool" implemented by the researchers of Pfizer Global Research and Development, $\mathrm{CH}_{3} \mathrm{OH}$ is considered as a benign and safe solvent in medicinal chemistry. Alfonsi, K.; Colberg, J.; Dunn, P. J.; Fevig, T.; Jennings, S.; Johnson, T. A.; Kleine, H.P.; Knight, C.; Nagy, M. A.; Perry, D. A.; Stefaniak, M. Green Chem. 2008, 10, 31-36.

43. Chakraborti, A. K.; Bhagat, S.; Rudrawar, S. Tetrahedron Lett. 2004, 45, 7641-7644.

44. Sithambaram, S.; Ding, Y.; Li, W.; Shen, X.; Gaenzlera, F.; Suib, S. L. Green Chem. 2008, 10, 1029-1032.

45. Raw, S. A.; Wilfred, C. D.; Taylor, R. J. K. Org. Biomol. Chem. 2004, 788-796.

46. Jeena, V.; Robinson, R. S. Beilstein J. Org. Chem. 2009, 5, No. 24.

47. Hanmantha Rao, M.; Pandu Ranga Reddy, A.; Veeranagaiah, V. Indian J. Chem. 1992, 31B, 88-91.

48. Rueping, M.; Tato, F.; Schoepke, F. R. Chem. Eur. J. 2010, 16, 2688-2691.

49. Loriga, M.; Nuvole, A.; Paglietti, G.; Fadda, G.; Zanetti, S. Eur. J. Med. Chem. 1990, 25, 527-532.

50. Chang, X.; Jiang, N.; Zheng, H.; He, Q.; Hu, Z.; Zhai, Y.; Cui, Y. Talanta 2007, 71, 38-43.

51. Nasielski, J.; Heilporn, S.; Nasielski-Hinkens, R.; Geerts-Evrard, F. Tetrahedron 1987, 43, 4329-4338. 